\title{
Re-telling: A Narrative inquiry of Indonesian graduate students' speaking experiences in a United Kingdom university
}

\author{
Mukhlash Abrar \\ Department of English Education, Faculty of Teacher Training and Education, Jambi University, Mendalo Darat, \\ Jambi Luar Kota, Mendalo Darat, Jambi Luar Kota, Kabupaten Muaro Jambi, Jambi 36657, Indonesia
}

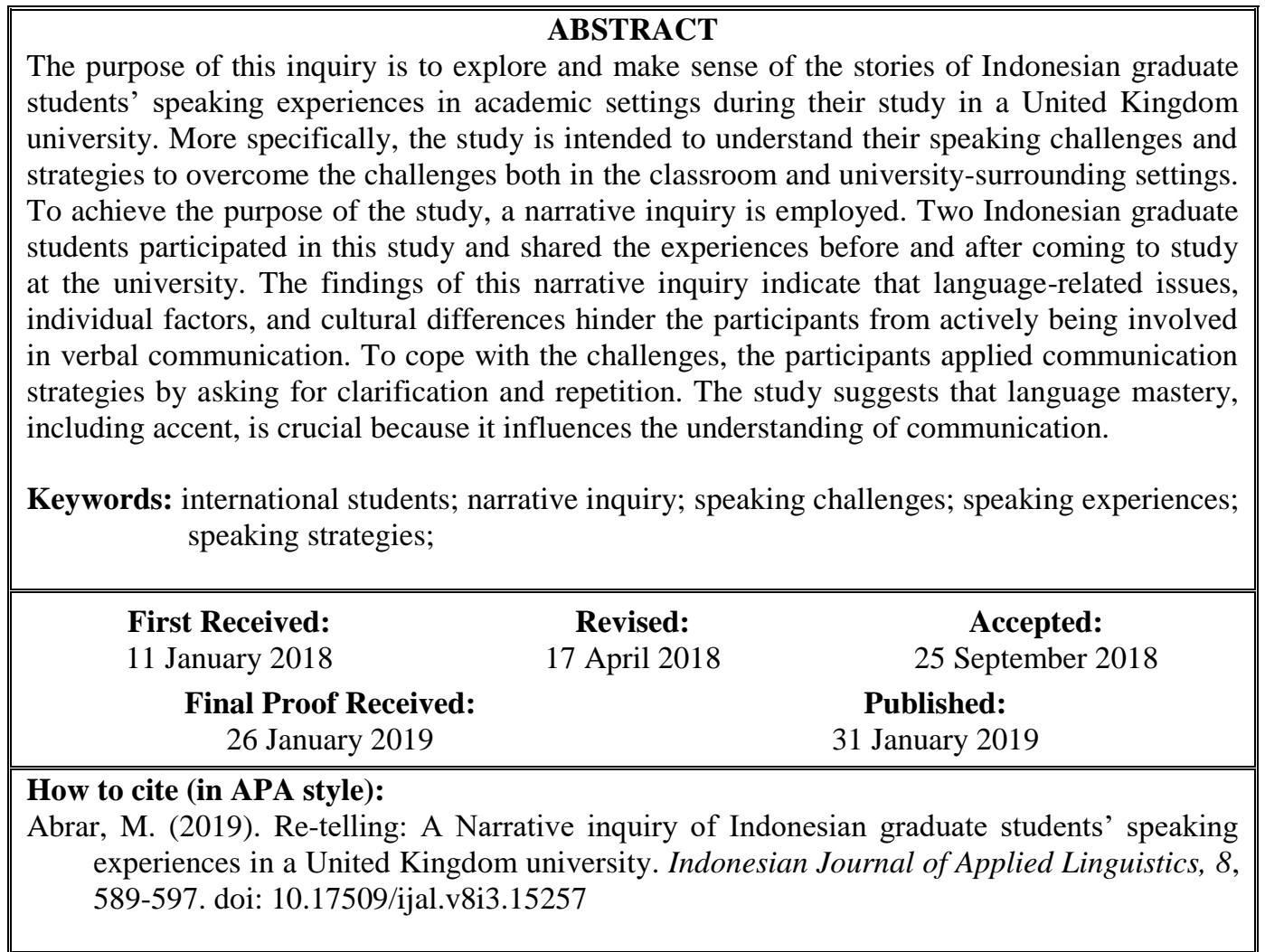

\section{INTRODUCTION}

"The limits of my language mean the limits of my world."

The above quote from Ludwig Wittgenstein, one of the most influential philosophers of the twentieth century, has indirectly made me realise the importance of mastering (second/foreign) language as a method of engaging with others from different cultural backgrounds. This quote implicitly indicates that the degree of my competence in other languages does limit how I live, socialise, and experience life. In a nutshell, if my speaking skill is not at a high enough level, it limits my ability to actively communicate and socialise with others in a diverse and multi-ethnic community or institution, such as English-speaking countries and/or English universities. In addition, my experience as an international student at one of the United Kingdom (UK) universities reinforces my perception that spoken interaction plays a pivotal role in academic life.

In 2015, I began my doctorate study programme at the university. I was confident that I would not encounter any verbal difficulties in communicating with other students and/or staff from different cultural backgrounds, in particular, those who are native English speakers or local speakers. My confidence was based on a very satisfying result on my speaking-Englishproficiency test I had taken before registering myself to university. Moreover, I graduated from an English study department, having achieved both undergraduate and 
master's qualifications. However, what I experienced at the beginning of my first year of study was completely different from what I had initially anticipated. My confidence faded away when I started attending my first class. I struggled to express my thoughts and ideas with my local friends owing to the different English-speaking accents being used. Interestingly, whenever I had discussions with other international students, mostly Asian, I found it enjoyable and could comprehend the conversation. This experience has triggered my desire to undertake this study and confirms what Clandinin and Connelly (1998) claim that "experience is ... the starting point and key term for all social science inquiry" (p.153).

Drawing on the approach of narrative inquiry, the present study aims at exploring and making sense of the stories of International Indonesian graduate students (IIGS) on their speaking experiences in academic settings. More specifically, it is intended to understand the participants' experience of speaking in (i) lectures/tutorials, and (ii) social contexts in the university. For this purpose, I will follow one primary guiding question: What stories do the participants tell about the speaking experiences while studying at a UK university? In order to answer this broad question, I will begin asking them a more concrete question: Can you tell me about your first time attending your module at the university? The question, although it seems specific, leaves room for participants to link their particular speaking experiences.

\section{Speaking a foreign language}

The term speaking literally means talking to other individuals. It, in a broader context, is an interactive process in the oral mode to express thoughts, opinions, and ideas, which involves more than just articulating words through an oral cavity. According to Chaney and Burk (1998), speaking is "the process of building and sharing meaning through the use of verbal and nonverbal symbols, in a variety of contexts" (p.13). Brown (1994), and Burns and Joyce (1997) separately conclude that speaking is an interactive process between speakers and hearers, which involves producing, receiving, and processing information. This suggests that speaking is a complex process of communication by which people exchange information, feelings, and meanings through verbal and non-verbal messages. In line with this concept, speaking a foreign language can be assumed as the communicative process of constructing meanings by using others' native language. Its process can be very challenging for non-native speakers because they are required to have a certain level of competence. Nunan (1999, 2003) and Hinkel (2011) outline that speaking (other languages) skills do require speakers' competence both in linguistics and sociolinguistics. Moreover, Shumin (2002) asserts that speakers' adequate speaking competence is a significant factor in foreign language interaction. It is evident that language proficiency and appropriateness are two demanding factors of speaking in other languages.
Owing to its complexity, speaking a foreign language is arguably challenging for non-native speakers and is often attributed to several factors. This includes lack of language proficiency (Abrar \& Mukminin, 2016; Lee, 2009), problem in listening ability (Doff, 1988; Shumin, 2002), cultural differences and lack of topical knowledge (Bachman \& Palmer, 1996; Morita, 2000), speaking condition (Nation \& Newton, 2008), and affective factors (Abrar \& Mukminin, 2016; Gardner \& McIntyre, 1993; Horwitz et al., 1986; Lee, 2009; Oxford, 1998; Palacios, 1998; Price, 1991; Krashen, 1982). Furthermore, Ur (1999), specific to a classroom context, ascertains that inhibition, nothing to say, low participation, and mother-tongue use are four prevalent factors which lead to students' speaking difficulty. These challenges may hinder non-native speakers, including Indonesian students, to communicate actively in academic settings.

Although it seems complicated and challenging, speaking is a crucial language-skill for foreign language learners to master (Egan, 1999; Kayi, 2012). It is a medium for them to express ideas, thoughts, and opinions to the other people. Having a good speaking skill, in an academic context, makes it easier and incumbent for them to participate in academic activities, including discussion, seminar, and supervision.

\section{Recent studies on speaking the foreign language}

Speaking has always been an appealing topic to be discussed and explored in the context of second/foreign language since it is one of the most important language skills to master. Until recently, a number of studies have investigated the related issue from various different perspectives. Of the existing studies exploring the issues of speaking in a foreign language, many are surveybased (Abrar, Failasofah, Fajaryani, \& Masbirorotni, 2016; Al-Jamal \& Al-Jamal, 2014; Riyaz \& Mullick, 2016; Çağatay, 2015; Keong et al., 2015; Liu, 2006; Öztürk \& Gürbüz, 2013; Qaddomi, 2013; Tuan \& Mai, 2015; Wei \& Zhang, 2013). These quantitative studies have, in most cases, examined the affective factors in speaking foreign languages and/or the encountered speaking problems faced by EFL learners. These studies reported fruitful findings of which linguistic competence and psychological effects are two prevalent factors which impact upon students' oral communication in foreign languages. Nevertheless, the information was limited in demonstrating how EFL learners perceive speaking in foreign languages. Therefore, it is significant to investigate the phenomenon in qualitative methodological studies to get in-depth information on the related issue.

Some studies, conducted in qualitative methodology, focus on the learners' challenges in speaking a foreign language (Abrar \& Mukminin, 2016; Al-Hosni, 2014; Lee, 2009; Morita, 2000). Abrar and Mukminin (2016) explored Indonesian international graduate students' lived experiences in engaging classroom discussion. Through phenomenological study, they interviewed eight Indonesian graduate 
students and revealed some challenging factors for the participants to actively participate in classroom verbal communication, including language barriers, individual matters, and academic culture differences. They also identified verbal responses, learning sources, and positive motivation as the strategies used by the participants to overcome the challenges in speaking. With a similar approach, Lee (2009) investigated the factors that influenced the oral classroom participation of six Korean students attending graduate school in the US. His research indicated that the participants encountered multiple layers of affecting-factors to orally participate in their classrooms, such as English language ability, sociocultural differences, individual differences, and classroom format. Other studies (Al-Hosni, 2014; Morita, 2000), by employing various perspectives in data collection, suggest that linguistic, psychological, and cultural factors were the dominant issues in speaking the foreign language. Their studies gave clear pictures about the real speaking problems faced by NNS of English. These above studies have provided valuable information on speaking foreign language issues, but they were only limited to specific time. Therefore, by employing a narrative inquiry, I hope this research can shed some light on EFL learners' speaking experience over time and address the gap in the study.

\section{METHOD}

\section{Study context}

The central focus of this study is to engage a small narrative inquiry in which I collected narrative data from a small number of IIGS experiences of speaking English in the context of a UK university. In accordance with its purpose, a narrative inquiry approach seems the best match for this study as it gives prominence to human experience and captures "detailed stories of life experiences" of individuals (Ary, Jacobs, Sorensen, \& Walker, 2010, p.470)

\section{Narrative inquiry}

The term narrative inquiry was first used in the educational research field in 1990 by Connelly and Clandinin. They established the educational importance of narrative as a research methodology (Connelly \& Clandidin, 1990) based on Dewey's philosophical tradition that claims education, experience, and life are interrelated (Dewey, 1938). This approach is known to have "a long intellectual history both in and out of education" (Connelly \& Clandinin, 1990, p.2), including in the discipline of anthropology, linguistics, literary theory, philosophy, theology, women studies, organizational theory, psychotherapy, geography, law, and medicine (Craig, 2007). The wide use of narrative in and across disciplines reinforces narrative inquiry as a widely acknowledged approach which is able to generate insights and to foster multiple interpretations of the phenomenon being studied.

Narrative inquiry, as its name suggests, can generally be defined as a qualitative approach which captures the personal and human dimension of lived experiences and presents them narratively. Connelly and Clandinin (1990) elucidate that narrative inquiry is the study of how humans experience the world. Similarly, Moen (2006) outlines that a narrative approach focuses on the meanings and values that individuals attach to their experiences through the stories they tell and share. Furthermore, Clandinin, Pushor, and Orr (2007) underscore that the narrative is "the study of experience as story" (p.22). These ideas imply that narrative inquiry approach attempts to understand how people think and experience through events and what they value. For that reason, I applied narrative inquiry in this study as a way to make sense of understanding my participants' experiences. I fully understand that the enquiry is subjective, but it captures the complexities of meanings embodied within the stories representing an in-depth analysis of data.

\section{Participants}

The Indonesian students who, by the time of the study, were studying at one of UK universities were purposely selected to engage in this narrative inquiry. To select the participants, I prioritised their feasibility for inclusion. They needed to have been previously engaged with learning experiences in a classroom-based mode at the university. This is crucial as the aim of this study is to explore the participants' speaking experiences in the academic contexts both inside and outside of classroom settings. The selection was also based on the participants' willingness to get involved in this study. Only those who signed and returned the research consent form became the participants of the study. All two participants, -Zee and Dee- are pseudonyms in this study. Zee, a male in his mid-20s, is a master's programme student within the School of Electronics, Electrical Engineering and Computer Sciencesmajoring in computer science. Another participant is Dee, a female in her early 30s who enrolls Teaching English to the Speaker of Other Language (TESOL) master's programme at the school of School of Social Sciences, Education and Social Work.

\section{Narrative tool, interpretation, and trustworthiness}

To obtain the stories in relation to speaking experiences by students, an in-depth narrative interview was used. The interview primarily focused on the participants' speaking experiences in the university context and held in the language with which the participants were most comfortable. In other words, I allowed the participants to speak either in Indonesian or English when they told their stories. Among the participants, one of them used English to share the stories, and therefore grammatical errors appeared in the interview extracts. My interview with each participant lasted for about 20-30 minutes, and I tried to minimise my personal reaction during the interview to avoid my influence on the stories. In order not to miss the participants' stories, the interviews were by agreement verbally recorded via a digital voice recorder. Additionally, I also noted my observation 
during the interview in the form of memos to help me understand the context of the participants' story (Polkinghorne, 2005).

After the data had been gathered, I began the narrative analysis by carefully transcribing the interview recordings myself and reading the transcription repeatedly. In the process of retelling the stories, I narrated every event, story, and experience that the participants told me by connecting the place and time in a meaningful way. Lastly, I used a cross-case analysis technique (Creswell, 1998) to manage the complexities of the stories into manageable themes and sub-themes, to find the similarities and differences among the stories, and to relate the findings to the existing literature of the related studies.

To ensure the trustworthiness (Lincoln \& Guba, 1985) and verification of the narrative interview data and to minimise interpretation in the final report, I included the participants in this process by returning both the transcriptions of the stories and the analysis with the aim of getting their feedback and comments. This process is part of relational responsibility in the narrative inquiry (Clandinin \& Connelly, 2000) to negotiate boundaries, anonymity, and ethical issues with their participants.

\section{FINDINGS}

\section{The told stories}

Within this section, I retold the stories shared by the participants regarding their English-speaking experiences in the context of a UK university. The narratives of each participant - including their past experiences in learning languages, and speaking experiences both in classroom and universitysurrounding settings - were separately presented.

\section{Zee's story: I eventually adjust myself}

Zee has been learning English for more than 10 years. He had his first English lesson during his first year of junior high school. He continued to learn English until his undergraduate education as it was a compulsory module to take. He explained that the language learning, for the most part, was less interactive and communicative. The teachers focused the teaching on receptive skills, and as a result, he rarely spoke the language. Although he felt that his English was inadequate, he was determined to continue his study overseas, and he began seriously practising his English a year before his leaving to study in a UK university. It was really difficult for him at the beginning, but he finally could manage it well.

\section{Speaking experiences in the classroom setting}

Zee felt very motivated to come to his first class at the university, and at the same time, he was also curious to find out what his classroom would look like. When he attended his first meeting of the module, he felt a little bit surprised because the class size was quite big. He explained that the total number of students was around
30 and most of them are local (Northern Irish) students. Besides himself, there were only a few other international students from China, India, and African countries. In his first meeting in the classroom, he thought that the process of learning ran well and thus completed the rest of the module classes. Most of the time Zee understood the whole module materials explained by his lecturers as they spoke English clearly and slowly. When he interacted with his tutors, he recalled that the conversations were generally comprehensible and he could adjust to the situation quite fast. He could simply respond to the conversation and catch up with the ideas, except when the lecturers spoke too fast and/or mentioned non-familiar technical terms, such as "offshore" and "in-shore." Nevertheless, he revealed that the interaction between the students and tutors in the classroom was infrequent as the majority of the study is not social science-based. He concretely described the typical classroom learning and interaction he experienced when saying:

\begin{abstract}
"...because I am studying in the electronic major, we [mostly] have the lecturing session only. The lecturers just [described] the slide in the class yeah and then sometimes they [gave] more examples with more explanations. I [and my classmates] rarely [asked] the questions because everything [was described in the slide] and a bit clear".
\end{abstract}

Unlike with the module tutors, interactions with his classmates during lecturing sessions were more intense and recurring. He actively asked and/or answered questions regarding the materials in the classroom. However, the interaction was sometimes not an easy activity for him as he found it challenging to communicate with native speakers. He experienced multiple technical-language problems, including issues with grammar, word choice, and the speed of the speech/conversation. He also had to adjust to a very distinctive communication feature "Irish-English accent" which he had never experienced before. Therefore, he often guessed and inferred the meaning. Whenever he found no clue to understand any pieces of information, he asked his NI classmates to repeat the sentences more than once. Having such problems in communication with his NI friends did not make him feel down or lose confidence; in fact, it encouraged him to speak more. On top of that, he now does not really worry about the way he speaks like he used to and so these experiences seem to have had a positive long-term impact. He further admitted that his strategy to keep in touch with NI classmates seems effective because, as time goes on, he begins adjusting himself within the conversation; even though he still faces the same challenges. He said, "And, after months or today, it still [happened] to me when I [talked to] Irish friends, but not too often."

Zee, then, continued his stories about his interaction with other international students in the classroom. Overall, he revealed that communication 
with them was a lot easier compared to NI students. When he interacted with international student classmates, he did not find any major speaking difficulties. He could understand and respond well. He only sometimes found it a little bit challenging to talk to his Chinese friends due to their distinctive pronunciation. He shared his experience with a smile:

\begin{abstract}
They talked really different [from] the natives as well and others. For example, at that time, [my Chinese friend mentioned a] word that actually I know, but I [couldn't] understand it. He [wanted to say] "you are friendly", but [instead he said] 'friely' without 'nd'. It was like [something's missing], and then he showed me the dictionary and I [realised he meant 'friendly'].
\end{abstract}

\section{Speaking experiences in university-surrounding settings}

Zee is a reserved person, and his interaction outside the classroom was not often. He recalled that he had his first interactive 'chitchat' when he participated at the university induction days. During the event, mingling with other students was not easy, but the interaction with the university staff was generally pleasant and informative. He could get involved in the conversation with staff as they talked clearly and seemed to know how to communicate with international students. Zee further explained that most staff at the university sites, including the library, students' guidance centre, and student union were very helpful and friendly. He gave this explanation when asked to recall his experience with the university staff,

\begin{abstract}
Another experience [outside the classroom was] to have meeting with one of officers [who helped] international students...I am happy with the chat and at that time I [felt] so close with the Irish woman, the officer, and talked more that I used to talk with other people. The way she talked [was] easy to understand and then also she had many topics to talk.
\end{abstract}

Although Zee earlier stated that his communication with the university staff was relatively easier, he noted that sometimes he needed to adjust the situation, particularly in the first meeting. The main reasons for this were that he did not really know what he was supposed to say and often felt a little bit awkward. $\mathrm{He}$ haltingly shared his speaking experience with his dissertation supervisor.

When my first time [talked to] my supervisor, I [actually had] got the title and the topic about my research... because the topic [of my research] is quite new for me and I have not [had] enough expectation of the result from analysis, I felt rigid, lost for words and a bit hard to explain to supervisor. But, for the second-time I [met] my supervisor, it [became] easier to explain.

After explaining his speaking experience with his supervisor, Zee explained that his interaction with friends outside of the classroom setting around the university really depended on his mood. Whenever he was in a good mood, he could eagerly and interactively talk to his friends. On the contrary, if he was reluctant to talk, he rarely addressed queries and just answered the questions briefly. He put in words "Laziness to talk really disturbs [my way] to speak even with my friends, even my close friends. I just [talked] what I need and also gave short response [to] the questions".

\section{Dee's story: Speaking English is not a serious matter for me}

Since she was a child, Dee had shown her desire to learn English. She loved listening to English songs and watched English movies. In fact, she formally started learning English when she was in the fifth grade of elementary school, but it was limited to vocabulary only. Her English language skills did not progress much when she was in secondary school because her English teachers emphasised reading and grammar in their teachings. Thus, she could not produce longer sentences. Her desire to speak English led her to study the language seriously. She then pursued her undergraduate degree in an English teaching department. She worked hard in her study and was deemed to be making satisfactory progress. As the proverb says, "what you plant is what you reap," she could fluently speak English when she graduated from the university. Before pursuing her master's programme at a UK university, she worked as an English teacher and communication in English was not something for her to worry about.

\section{Speaking experiences in the classroom setting}

Dee, giggling, expressed that a classroom is a comfortable place for her to study. She likes it because she can focus on her study, meet and interact with her tutors and friends. She described that her class size is quite big consisting of more than 30 students and is dominated by Asian students, especially from China and Indonesia. For her, communication during the class was not really difficult as she is an English programme graduate and most of her peers are not natives. The pivotal factor that affected her speaking within the classroom activities was her mood. She explained " $m y$ speaking in the classroom really depended on my mood. What I meant is if I was in a good mood, I could speak English all the time, but if not, I couldn't even want to speak and suddenly felt blank".

Although she could speak well in the classroom, this is not to say that Dee did not find any challenges while interacting with her classmates. She occasionally needed more time to understand her classmates' English-accent and pronunciation. She even had to deal with her anxiety whenever she could not get the idea of what to say during conversations with her foreign classmates. Dee detailed,

It's not really difficult for me to speak with Chinese friends, but having communication with European classmates, such as Northern Irish was 
a bit challenging. Owing to their distinctive English-accent, I sometimes completely couldn't get the point of conversation. I also felt nervous whenever I sat beside them and couldn't understand their speaking.

She further added,

With my Chinese classmates, the only problem is their pronunciation. They wanted to say something but pronounced the words unclearly/differently. So, I barely understood their utterances sometimes. That's my experience with my classmates, but overall I am okay.

After she spoke honestly of her speaking challenges with her classmates, I became curious to know how she managed the situation. I asked, "what strategy did you use?" She seemed to know what I meant with my question, and she promptly answered: "I often confirmed them the meaning by saying do you mean this?" As our conversation continued, Dee enthusiastically talked about her interaction with her module tutors in the classroom. She previously mentioned that she, in the autumn semester, had had 4 modules and studied with 5 different tutors - 1 American, 1 Spanish, and 3 Northern Irish. Her communication with tutors was generally fine because the tutors were very communicative and spoke the language clearly. She also revealed that she actively participated in most modules, asked questions, did a presentation, responded to queries, and even had consultations with the tutors. As she continued her story, she recalled a moment when she was a little bit confused studying in the classroom. She assumed that it was because of the cultural difference. She specifically stated,

There was one moment I could not understand what the lecturer said in the classroom. That was when he tried to make some jokes when teaching. For me, I did not find it funny and couldn't understand them at all, but all laughed aloud.

\section{Speaking experiences in university-surrounding settings}

When Dee was asked about her speaking experiences at the university, outside of the classroom settings to be exact, she spontaneously said, "it is not really a problem for $m e$ ". She is an outgoing student and loves to interact with other people. During her study, she often spoke to the staff at the university. She recalled that her first contact with staff was when she registered herself at the university. She commented "It was definitely okay" to talk to the staff at that time. She could grasp the idea of the conversation easily and clearly understand what the staff said to her. Thus, the application process was relatively fast and smooth. A week later, she attended the induction days for new students. She met university staff during the event and had some chat with them. She once again stated that she did not find it hard to interact with them. As our conversation continued, she shared similar experiences speaking to the staff in other places surrounding the university, including the library, graduate school, student guidance centre, university health centre, physical education centre, student union, and international office. She then excitedly made her final comments about her communication with staff in the following remark:

I can say it's pretty easy to communicate with the university staff. They seem know to talk to international students. They speak relatively slow and very clear, and their accents seem to be adjusted. So, in general, it is not difficult to speak to them.

Dee revealed that her spoken interaction with friends surrounding the university was quite the same with the staff. The difference was only in its degree of formality. She so much felt close to her friends when she had some academic discussion and/or chat with them. She could interactively take part in a conversation, express her feelings freely, and speak without any hesitance. The topic of conversation can also vary from academic to personal matters. She then admitted that the more she interacted with her friends, the more she became aware that it is important to maintain good relationships. She knew her friends better and learned many life-aspects from them, including their cultures. She specifically explained what she learned from her Chinese mates,

In Chinese culture, they said it isn't polite to say no. They use different phrases to indicate their rejection/denial to something. For example, when I asked do you want to go there? My Chinese friend responded hmm.let see. It actually means 'no.'

However, Dee seemed to limit her friends as she tended to hang out with her Indonesian or Chinese friends. She shyly said, "I often hang out only with Indonesian or Chinese friends. We sometimes had discussion in the library or at the university café. I didn't really talk to my European friends, only in classroom".

\section{DISCUSSION AND CONCLUSION}

I have so far narrated IIGS's English speaking experiences at the university context both in classroom and university-surrounding settings. As a part of the interpretive analysis process, I used the participants' narratives as 'a collective story' and addressed the interrelated themes and sub-themes that emerged from the stories through a cross-case analysis technique (Creswell, 1998). "The collective story gives voices to those who are silenced and marginalised and displays an individual story by narrating the experiences of the social category to which the individuals belong" (Richardson, 1997, pp.22). From the data interpretation, two salient themes from the participants' collective story have been identified, including speaking challenges and overcoming strategies. 


\section{English speaking challenges}

Speaking in a second/foreign language is arguably challenging for non-native speakers (Nunan, 1999, 2003; Shumin, 2002) as they are required to be proficient in both linguistic and sociolinguistic competence. The participants of this study revealed that they experienced some challenges in verbal communication although they have prepared their English before pursuing their study in the UK. Language-related issues, such as pronunciation, grammar, fluency, vocabularies, and accent are the major issues for their speaking. These results concur with some other research findings (Abrar \& Mukminin, 2016; Akasha, 2013; Bayley, Fearnside, Arnol, Misiano, \& Rottura, 2002; Lee, 2009; Nguyen, 2011; Novera, 2004; Wright \& Schartner, 2013) that language barrier is a prominent issue for non-native speakers in spoken interaction. Of five language-related issues, the accent was noted as the most frequent challenge for both participants. The accent is a unique way of pronouncing language influenced by speakers' native language or dialect (Edwards, 1997) and characterised with particular phonological variation, rhythmic stress and emphasis (Cheng, 1999; Lippi-Green, 1997; Stewart \& Vaillette, 2001). Both participants argued it is difficult to understand their NI classmates words because the way or accent they speak is different from what they have previously learned/heard, especially their intonation. This result indicated that accented speech is more difficult to understand than unaccented speech. In addition, unfamiliarity to the accent is one of the determining factors for the difficulty in communication. The other two communication challenges are individual factors and cultural differences. In terms of individual factors, both participants admitted that 'moods' play a significant role in their speaking involvement and motivation. When they were in a good mood, they actively participated in a conversation, and, on the contrary, they did not feel willing to speak when they were in a bad mood. It is in line with what Gendolla, Brinkmann, and Richter (2007) argue that mood influences someone's motivation and performance. Another individual factor that both participants encountered was a state of apprehension, worry, and fear known as anxiety (Chastain, 1988; Horwitz et al., 1986; MacIntyre, 1998). They, however, did not experience anxiety very often, only when they missed the ideas and interacted for the first time. The last communication problem is cultural differences. Cultures refer to shared values, principles, and norms of a particular group of people which provide them with ways of thinking and interpreting the world (Kiss, 2008). Thus, communication with people from different cultures is incredibly challenging. Both participants experienced this challenge in their communication. Dee, for instance, described that the jokes used in the classroom were not understandable because they were limited to a particular culture. Similarly, Zee explained that he has to adapt to eye-contact cultures when speaking. The findings of individual factors and cultural differences above are consistent with the findings of other studies (Abrar \& Mukminin, 2016; AlHosni, 2014; Garner, 1985; Lee, 2009; Morita, 2000; Novera, 2004; Wright \& Schartner, 2013).

Interestingly, the findings have highlighted that the participants find it easier to communicate with their tutor and university staff compared to their classmates. They commented that the staff seemed to know how to communicate with international students. The majority of staff speak relatively clearly and slowly, so they can adjust the conversation easily. This fact is reasonable as the UK University staff is reported to have continued training and one of the topics is about helping overseas students (Brown \& Atkins, 1986).

\section{Overcoming strategies to speaking challenges}

Another theme that has been identified from the participants' collective story is 'overcoming strategies.' This corresponds to the efforts that the participants used to solve their communication challenges in their spoken interaction. They both shared that asking for clarification and repetition is very effective whenever they do not understand the conversation due to the language or cultural problems. Having such attempts, they obviously apply speaking strategies (Douglas, 2007) to cope with their communication problems. Speaking strategies are crucial as they help the speakers to negotiate the meanings that are not shared with the speakers of the target language (O'Malley \& Chamot, 1990; Tarone, 1981). In addition, the results of this study confirm the findings of Abrar and Mukminin (2016) in their phenomenological study that non-native learners tended to use speaking strategies to participate in discussion/talk actively.

\section{LIMITATIONS}

This small-scale study has discussed the speaking livedexperiences of Indonesian graduate students while studying at one of UK universities in an academic context. However, this is not to say that this study itself is without limitations. Firstly, the participants may not be representative since they were solely limited to two Indonesian students studying in masters' programme. Further research could include a larger sample of Indonesian students from other degree levels, such as undergraduate and Ph.D. Secondly, this study solely focused on students' experiences, and tutors/university staff were excluded, so further studies might explore the faculty's speaking experiences communicating with international students; in particular Indonesians. Lastly, the results of this study cannot be generalised to the experience of students generally as it specifically investigates Indonesian students' lived-experiences. Nevertheless, further research in quantitative studies could use these results as a reference point for constructing questionnaires.

\section{ACKNOWLEDGMENT}

I would like to thank Prof. Ruth Leitch (Senior Lecturer, 
School of Social Sciences, Education, and Social Work, Queens University Belfast, UK) for her expert advice and comments on this paper.

\section{REFERENCES}

Abrar, M., \& Mukminin, A. (2016). International graduate classroom discussion engagement, challenges, and solving-strategies. Asia-Pacific Collaborative Education Journal, 12(1), 5-19. doi: 10.14580/apcj.2016.12.1.05

Abrar, M., Failasofah, F., Fajaryani, N., \& Masbirorotni, M. (2016). EFL student teachers' speaking anxiety: The case in one English teacher education program. Indonesian Journal of English Education, 3(1), 1-14. doi: 10.15408/ijee.v3i1.3619

Akasha, O. (2013). Exploring the challenges facing arabic-speaking esl students \& teachers in middle school. Journal of ELT and Applied Linguistics, 1(1), 12-31.

Al Hosni, S. (2014). Speaking difficulties encountered by young EFL learners. International Journal on Studies in English Language and Literature, 2(6), 22-30.

Al-Jamal, D.A., \& Al-Jamal, G.A. (2014). An investigation of the difficulties faced by EFL undergraduates in speaking skills. English Language Teaching, 7(1), 19-27. doi: 10.5539/elt.v7n1p19

Ary, D., Jacobs, L.C., Sorensen, C.K., \& Walker, D. (2010). Introduction to research in education. Canada: Cengage Learning.

Bachman, L.F., \& Palmer, A.S. (1996). Language testing in practice: Designing and developing useful language tests. Oxford: Oxford University Press.

Bayley, S., Fearnside, R., Arnol, J., Misiano, J., \& Rottura, R. (2002). International students in Victorian universities. People and Place, 10(2), 45.

Brown, H. D. (1994). Teaching by principles. Englewood Cliffs, NJ: Prentice Hall.

Brown, G., \& Atkins, M. (1986). Academic staff training in British universities: Results of a national survey. Studies in Higher

Education, 11(1), 29-42. doi: 10.1080/03075078612331378441

Burns, A., \& Joyce, H. (1997). Focus on speaking. North Ryde, N.S.W: National Centre for English Language Teaching and Research.

Çağatay, S. (2015). Examining EFL students' foreign language speaking anxiety: The case at a Turkish state university. Procedia-Social and Behavioural Sciences, 199(1), 648-656. doi: 10.1016/j.sbspro.2015.07.594

Chaney, A.L., \& Burk, T.L. (1998). Teaching oral communication in grades $K-8$. Boston: Allyn and Bacon.

Cheng, L.R.L. (1999). Moving beyond accent: Social and cultural realities of living with many tongues. Topics in Language Disorders, 19(4), 110. doi: 10.1097/00011363-199908000-00004

Clandinin, D. J., \& Connelly, F. M. (1998). Personal experience methods. In N. K. Denzin \& Y. S. Lincoln (Eds.), Collecting and interpreting qualitative materials (pp. 150-178). Thousand Oaks, CA: Sage.

Clandinin, D. J., \& Connelly, F. M. (2000). Narrative inquiry: Experience and story in qualitative research. San Francisco, CA: Jossey-Bass.

Clandinin, D.J., Pushor, D., \& Orr, A.M. (2007). Navigating sites for narrative inquiry. Journal of Teacher Education, 58(1), 21-35. doi: $10.1177 / 0022487106296218$

Connelly, F.M., \& Clandinin, D.J. (1990). Stories of experience and narrative inquiry. Educational Researcher, 19(5), 2-14. doi: 10.3102/0013189X019005002

Craig, C.J. (2007). Story constellations: A narrative approach to contextualizing teachers' knowledge of school reform. Teaching and Teacher Education, 23(2), 173-188. doi: $10.1016 /$ j.tate.2006.04.014

Creswell, J. W. (1998). Qualitative inquiry and research design: Choosing among five traditions. London: SAGE Publications.

Dewey, J. (1938). Experience and education. New York, NY: Macmillan.

Doff, A. (1988). Teach English trainer's handbook: A training course for teachers. Cambridge: Cambridge University Press.

Douglas, H. (2007) Teaching by principles: An interactive approach to language pedagogy. New York: Pearson Education.

Edwards, H. T. (1997). Applied phonetics: The sounds of American English (2nd edn.). San Diego, CA: Singular.

Egan, K.B. (1999). Speaking: A critical skill and a challenge. CALICO Journal, 16(3), 277-293.

Gardner, R.C. (1985). Social psychology and second language learning: The role of attitudes and motivation. London: Edward Arnold Publisher.

Gardner, R. C., \& MacIntyre, P. D. (1993). On the measurement of affective variables in second language learning. Language Learning, 43(2), 157-194. doi: 10.1111/j.14671770.1992.tb00714.x

Gendolla, G. H. E., Brinkmann, K., \& Richter, M. (2007). Mood, motivation, and performance: an integrative theory, research, and applications. In A. M. Lane (Ed.), Mood and human performance: Conceptual, measurement, and applied issues (pp. 35-61). Hauppauge, NY: Nova Science.

Hinkel, E. ed. (2011). Handbook of research in second language teaching and learning (Vol. 2). New York: Routledge.

Horwitz, E.K., Horwitz, M.B., \& Cope, J. (1986). Foreign language classroom anxiety. The Modern Language Journal, 70(2), 125-132. doi: 10.1111/j.1540-4781.1986.tb05256.x 
Kayi, H. (2012). Teaching speaking: Activities to promote speaking in a second language. The Internet TESL Journal, 12(11). Retrieved from: http://iteslj.org/Techniques/Kayi-TeachingSpeaking.html

Kiss, G. (2008). Tactics for removing cultural barriers: A practical approach to effective communication. AARMS, 7(3), 425-433.

Keong, Y. C., Ali, A. I., \& Hameed, F. W. (2015). Speaking competence of Iraqi EFL undergraduates of Garmiyan University. International Journal of Education and Research, 3(5), 157-170.

Krashen, S. (1982). Principles and practice in second language acquisition. New York: Pergamon Press.

Lee, G. (2009). Speaking up: Six Korean students' oral participation in class discussions in US graduate seminars. English for Specific Purposes, 28(3), 142-156. doi: 10.1016/j.esp.2009.01.007

Lincoln, Y.S., \& Guba, E.G. (1985). Naturalistic inquiry. Newbury Park, CA: Sage Publications.

Lippi-Green, R. (1997). English with an accent: Language, ideology, and discrimination in the United States. London and New York: Routledge.

Liu, M. (2006). Anxiety in Chinese EFL students at different proficiency levels. System, 34(3), 301316. doi:10.1016/j.system.2006.04.004

MacIntyre, P. D. (1998). A review of the research for language teachers. In D. J. Young (Ed.), Affect in Foreign Language and Second Language Learning (pp. 24-45). Boston: McGrew-Hill.

Moen, T. (2006). Reflections on the narrative research approach. International Journal of Qualitative Methods, 5(4), 56-69. doi: $10.1177 / 160940690600500405$

Morita, N. (2000). Discourse socialization through oral classroom activities in a TESL graduate program. TESOL Quarterly, 34(2), 279-310. doi: $10.2307 / 3587953$

Nation, I.S.P., \& Newton, J. (2008). Teaching ESL/EFL listening and speaking. New York: Routledge.

Nguyen, C.T. (2011). Challenges of learning English in Australia towards students coming from selected Southeast Asian countries: Vietnam, Thailand and Indonesia. International Education Studies, 4(1), 13-20. doi: 10.5539/ies.v4n1p13

Novera, I.A. (2004). Indonesian postgraduate students studying in Australia: An examination of their academic, social and cultural experiences. International Education Journal, 5(4), 475-487.

Nunan, D. (1999). Second language teaching \& learning. Boston: Heinle \& Heinle Publishers.

Nunan, D. (2003). Practical English language teaching. New York: McGraw-Hill/Contemporary.

O'malley, J.M. \& Chamot, A.U. (1990). Learning strategies in second language acquisition. New York: Cambridge University Press.

Oxford, R.L. (1998). Anxiety and the language learner: New insights. In J. Arnold (Ed.), Affect in language learning. (pp. 58-67). Cambridge, U.K.: Cambridge University Press.
Öztürk, G., \& Gürbüz, N. (2013). The impact of gender on foreign language speaking anxiety and motivation. Procedia-Social and Behavioral Sciences, 70(1), 654-665. doi: 10.1016/j.sbspro.2013.01.106

Palacios, L.M. (1998). Foreign language anxiety and classroom environment: A study of Spanish University students. University of Texas at Austin.

Polkinghorne, D.E. (2005). Language and meaning: Data collection in qualitative research. Journal of Counselling Psychology, 52(2), 137-145. doi: 10.1037/0022-0167.52.2.137

Price, M. L. (1991). The Subjective Experience of Foreign Language Anxiety: Interview with Highly Anxious Students. In E. K. Horwitz, \& D. J. Young (Eds.), Language anxiety: From theory and research to classroom implications (pp. 101-108). Englewood Cliffs, NJ: Prentice Hall.

Qaddomi, H. (2013). Investigating Al-Quds Open University students' EFL learning anxiety. AnNajah Humanities, 27(7), 1533-1562.

Richardson, L. (1997). Fields of play: Constructing an academic life. New Brunswick, NJ: Rutgers University Press.

Riyaz, H., \& Mullick, A.P. (2016). Problems in learning English speaking skill: A study of higher secondary students in Srinagar, India. International Journal of Interdisciplinary and Multidisciplinary Studies, 3(2), 59-69.

Shumin, K. (2002). Factors to consider: Developing adult EFL students' speaking abilities. In J.C. Richards \& W.A. Renandya (Eds.), Methodology in language teaching: An anthology of current practice. (pp. 204-211). Cambridge, U.K.: Cambridge University Press.

Stewart, T.W., \& Vaillette, N. (2001). Language files: Materials for an introduction to language and linguistics. Ohio: Ohio State University Press.

Tarone, E. (1981). Some thoughts on the notion of communication strategy. TESOL Quarterly, 15(3), 285-295. doi: 10.2307/3586754

Tuan, N.H., \& Mai, T.N. (2015). Factors affecting students' speaking performance at Le Thanh Hien high school. Asian Journal of Educational Research, 3(2), 8-23.

Ur, P. (1999). A course in language teaching: Practice and theory. Cambridge, U.K.: Cambridge University Press.

Wei, Y., \& Zhang, L. (2013). The survey on barriers of oral english learning for college students in China. English Language Teaching, 6(6), 68-76. doi: 10.5539/elt.v6n6p68

Wright, C., \& Schartner, A. (2013). 'I can't... I won't?'International students at the threshold of social interaction. Journal of Research in International Education, 12(2), 113-128. doi: $10.1177 / 1475240913491055$ 